\title{
Till minne: Erling Sandmo
}

Erling Sverdrup Sandmo rycktes bort under en skidtur i februari 2020, endast 56 år gammal. I ett slag förlorade Norden en av sina mest nyfikna, kreativa och generösa historiker.

Bergensonen Erling växte upp i ett akademikerhem och tog sin grundexamen i födelsestaden innan han växlade över till Oslo. Väl på Blindern riktade han in sig mot I600- och I700-talens rätts-, mentalitets- och kulturhistoria samtidigt som han gav sig hän åt filosofiska, estetiska och idéhistoriska diskussioner. Hans avhandling, som senare utkom som boken Voldssamfunnets undergang (1999), var inspirerad av Michel Foucaults tankar om förhållandet mellan kunskap och makt, en teoretiker som vid denna tid var kontroversiell i norska historikerkretsar men som Erling tog parti för i flera animerade debatter om postmodernismen och sanningsbegreppet under åren omkring millennieskiftet.

De rättshistoriska intressena skulle Erling därefter vidareutveckla i sin andra större bok, ett verk om Norges Hoyesterett åren 1905-1965.Vetgirigheten drev honom vidare till nya fält. Hans kanske största passion i livet, den klassiska musiken - under många år var han en omtyckt kritiker och förmedlare i NRK $\mathrm{P}_{2}$ och Morgenbladet - gjorde han också till föremål för akademisk analys.

Trots skiftande empiriska intressen återkom han alltid till historievetenskapens epistemologiska och ontologiska grundfrågor. Under sina år som professor i historia i Oslo skrev han Tid for historie (20I4, svensk utgåva 20I7), en ovanligt livfull och personlig introduktion till historiografi och historieteori. Ett tecken på den respekt han åtnjöt i sitt lands historikersamfund var att han 2020 postumt tilldelades Den norske historiske forenings stora utmärkelse, Sverre Steen-priset. Motiveringen löd: för att han i en ”årrekke markert seg som en førsteklasses representant for faget i offentligheten, og det ved å kombinere en høy teoretisk og metodisk refleksjon med en levende og inspirerende formidlingskunst, både i skriftlig og muntlig form”.

Under 20Io-talet ägnade sig Erling allt mer åt historiska kartor. Genom att studera dessa artefakter, materialiseringar av hur människan har konstruerat sin värld, kunde han få utlopp för sina global-, kultur- och kunskapshistoriska lidelser. Den finurliga essäboken Uhyrlig. Sjømonstre i kart og litteratur I49I-I895 (2017) och den internationella antologin Conceptualizing the World (2019, utgiven tillsammans med Helge Jordheim) vittnar 
om hans engagemang och kunnande. År 2017 anställdes Erling vid Nasjonalbiblioteket för att bygga upp ett nytt kartcentrum med bas i världens största samling av historiska kartor över Norden. Hösten 2019 stod den nya påkostade satsningen klar och som föreståndare presiderade Erling över den storstilade invigningen. Vid den nya centrumbildningen skulle han, med sin entusiasmerande begåvning och breda historiska bildning, verka som forskare och förmedlare under de kommande åren. Så blir det nu inte.

Som få andra odlade Erling kontakter med Sverige och svenska humanister, möjligen inte så underligt för en I6oo-talsexpert född den 6 november. Redan i början av I990-talet var han gästforskare i Eva Österbergs intellektuella gemenskap vid Historiska institutionen i Lund och han skulle återkomma till det sydsvenska lärosätet många gånger. Hans forskning kom flera gånger att handla om svenska fenomen - från gustavianska operor till Olaus Magnus kartor - men än viktigare var hans vilja att ständigt återvända till Sverige och interagera med svenska forskare. Med glädje deltog han i konferenser, disputationer och seminarier i vårt land. I de sociala sammanhang som kringgärdade dessa evenemang fick många svenska historiker stifta bekantskap med denne varme, humoristiske norrman med sin omisskänneliga bergensiska. Förbluffade noterade vi att Erling visste lika mycket om svensk gastronomi, fotboll och populärmusik som vi var okunniga om deras norska motsvarigheter.

Vi lärde känna Erling på allvar 20I4. Under detta år råkade det sig så att både han och Johan var gästforskare vid Lorraine Dastons avdelning vid Max-Planck-Institut für Wissenschaftsgeschichte i Berlin. De fann varandra snart och tillsammans började de utforska det som tyskarna då hade börjat tala om som Wissensgeschichte, ett bredare, mer kulturellt och samhälleligt inkluderande studium av kunskap än vad som vanligen var fallet inom bistory of science.

Tillbaka i Skandinavien beslöt sig Erling och Johan för att försöka etablera detta nya fält - kunskapshistoria - på nordliga breddgrader. De vände sig till tre nydisputerade historiker: Anna och David i Lund samt Kari Nordberg i Oslo. Med gemensamma krafter började vi bygga den forskningsmiljö som nu har vuxit ut till ett finmaskigt internationellt nätverk och som sedan 2020 har institutionaliserats i form av Centrum för kunskapshistoria (LUCK) i Lund. Erling spelade en avgörande roll för att introducera kunskapshistoria $\mathrm{i}$ vår del av världen, och han var bland annat en av redaktörerna för vår första gemensamma antologi, Circulation of Knowledge (2018).

Erling var medlem i Scandias redaktionsråd och deltog i arbetet med att utveckla tidskriften. År $2014 \mathrm{skrev}$ han ett rikt och engagerat bidrag till temanumret "Därför är vi historiker". I detta berättade Erling bland annat om en undersökning som en kollega till honom gjort om vad som drev 
studenter och forskare att ägna sig åt historia. Svaren som de två grupperna gav var förvånansvärt lika. De präglades av samma allvar, höga ambitioner och en stark tro på att historia var någonting djupt existentiellt och betydelsefullt. Erling tolkade detta som att historikerskrået präglades av "en felles, allmen kultur". Historiker ingick i en värdegemenskap. Det var inte de gemensamma kunskaperna, intressena eller färdigheterna som förenade - utan tron. Decennier av professionellt arbete gjorde inte "historikernes forhold till verdifelleskapet mer analytiskt. Det bara styrket och bekreftet felleskapet." Därigenom, menade Erling, uppvisade historikerskrået kanske djupast sett ett släktskap med andra trossamfund.

Vad passagen också vittnade om var att Erling själv satte stort värde på vetenskapliga gemenskaper och vänskaper. Han odlade dem på ett rakt igenom öppet och generöst sätt. Senvåren 2017 var David gästforskare i Oslo. Erling var en oöverträffad värd. Han hjälpte David att hitta boende, satte honom i kontakt med kollega efter kollega, och öppnade dörren till sitt hem och sin familj. Tillsammans med Erlings livskamrat Brita och deras dotter Agnes firade de I7:e maj ihop och åkte till Valdres på hyttetur. Under timmarna i bilen vindlade samtalen fram och tillbaka. Vid ett tillfälle frågade Erling om David och Brita skulle fortsätta att vara historiker om de var de enda i världen. Det nekande svaret var givet. Utan gemenskapen var livet som historiker inte meningsfullt. Det var tillsammans med andra, i "en felles, allmen kultur", som det yttersta värdet låg.

Vi minns Erling som en spirituell, inlevelsefull, underhållande och inspirerande historiker med ett ovanligt öppet sinne. Han var en oförliknelig person som kunde se tillvarons storhet genom det partikulära och udda; han kunde aldrig kunde låta bli att fängslas av det förflutnas rikedom. Med sin helt igenom prestigelösa attityd kom han ofta i samspråk med yngre forskare och lät sig gärna smittas av deras entusiasm inför sitt ämne - oavsett om det gällde spöken, dueller eller efterkrigstidens miljörörelse. Erling var en av sin generations största nordiska humanister och en fantastiskt levande människa.

Johan Östling, Anna Nilsson Hammar \& David Larsson Heidenblad Föreståndare respektive biträdande föreståndare för Centrum för kunskapshistoria (LUCK), Lunds universitet 